Article

\title{
Black Boys' and Young Men's Experiences with Criminal Justice and Desistance in England and Wales: A Literature Review
}

\author{
Laura Robertson and John Peter Wainwright *(D)
}

School of Social Work, Care and Community, University of Central Lancashire, Preston PR1 2HE, UK;

laura.robertson@povertyalliance.org

* Correspondence: jpwainwright@uclan.ac.uk

Received: 16 March 2020; Accepted: 5 April 2020; Published: 15 April 2020

check for updates

\begin{abstract}
Black boys and young men are over-represented in the youth and adult justice systems in England and Wales. Despite the Lammy Review (2017) into the treatment of and outcomes for Black, Asian, and minority ethnic individuals (BAME) in the criminal justice system, the disproportionate numbers of Black boys and young men at all stages of the system continue to rise. There has been limited qualitative research of Black boys' and young men's experiences with the justice system in England and Wales. In particular, there is a lack of evidence on their experiences with sentencing and courts. What is known tends to focus on Black, Asian, and minority ethnic and/or Muslim men's experiences more generally. A lack of critical understanding of the specific experiences of desistance by young Black men has been criticised in the literature. Set in this context, this review of UK literature focuses on the following questions: (1) What are Black boys' and young Black men's experiences with the youth and criminal justice systems in England and Wales? (2) What does research tell us specifically about their experiences with desistance?
\end{abstract}

Keywords: black boys and young men; youth and criminal justice; desistance

\section{Introduction}

This paper will explore, through a literature review, how the genealogy of race $^{1}$, of racialising ethnic difference of Black, Asian, and minority ethnic (BAME) boys and young men, is experienced by them in the criminal justice system (CJS). Despite downward trends in the numbers of children and young people in the youth and adult CJS in England and Wales, the proportion of Black and dual ethnicity boys and young men has been increasing. Black children/young people are over-represented in every stage of the youth and adult justice systems in England and Wales. Despite recognition of this disproportionality by successive governments, there is a lack of qualitative research on the subjective and lived experiences of Black boys' and young men's experiences. The existent literature tends to focus on the experiences of BAME and/or Muslim men rather than young Black men. The literature on BAME experiences with the justice system has emphasised a need to consider intersecting identities, particularly in relation to understanding young Black men's experience with resettlement and desistance. However, desistance literature has lacked a specific focus on young Black men's experience of desistance. Whilst recent reviews of evidence have highlighted the complex and multitude of factors that underpin disproportionality in the system (Mullen et al. 2014; Hunter 2019), there is a need to

1 Race is not a satisfactory term, as it is a social construction based on negative ethnic characteristics. However, it is used in this article as a means of articulating differentiation and othering through power and as a tool for analysis of this difference. 
also understand what research tells us about their specific experiences of desistance. This literature review was conducted to address the following questions: (i) What are Black boys' and young men's experiences with the CJS in England and Wales? (ii) What does research tell us about their specific experiences with desistance?

\section{Literature Review Method}

This literature review was originally conducted in 2016 and updated in December 2019. Relevant databases were searched including the following: Criminal Justice Database, Criminal Justice abstracts, Scopus, and Socindex. Search terms included "Black and minority ethnic", "African or Caribbean", "youth justice system", "criminal justice system", "young men", and "desistance". Due to time constraints, it was not possible to conduct a systematic review of the literature. Therefore, the limitations of this literature review should be acknowledged, including the facts that only four databases were searched, a systematic record of papers was not made, and the research studies included were not critically appraised. Given the dearth of literature in this field, the aim was instead to identify the key issues and gaps in knowledge in the field. This literature review was specifically focused on the experiences of Black (African/Caribbean) boys and young men, but due to a lack of literature specifically on this group, this review also drew on studies more broadly focused on the experiences of BAME groups. This review drew on literature published in England only, as the focus was to understand experiences specifically in the English and Welsh youth and criminal justice systems. An initial scoping of the literature revealed a lack of recent, qualitative empirical studies. Therefore, it was decided to include literature published over the last 15 years despite recognition of the changes to the youth and adult CJS during this time.

\section{Summary of Literature Review Themes}

This literature review was focused on addressing two key questions: (i) What are Black boys' and young men's experiences with the CJS in England and Wales? (ii) What does research tell us about their specific experiences with desistance? Across the literature, several key themes can be identified. First, that black boys and young men experience discriminatory practices is evident in official statistics and studies conducted across all stages of the youth and adult criminal justice system. A wider body of literature on BAME experiences, drawn on for the purposes of this review, more broadly and clearly conveys experiences of differential treatment as a result of race, ethnicity, and faith (May et al. 2010; Mullen et al. 2014; Hopkins 2015; Barn et al. 2018). Second, a small but important body of research has highlighted that the gangs label is disproportionately attributed to BAME people (Williams and Clarke 2016). Lastly, a key focus of this review on desistance, whilst resting on a small body of studies, reveals significant gaps in the resettlement provision for BAME people leaving custody, with evidence of struggles to access accommodation and employment (Calverley 2013). A lack of knowledge specifically on how identity change may operate as a mechanism in the desistance of UK-based minority ethnic groups has also been raised (Calverley 2013; Glynn 2014). Deficiencies in current understandings of desistance in relation to BAME people has led to calls for an "intersectional model of desistance" (Glynn 2016). This review of the literature, whilst not systematic, clearly identifies the need for further research particularly on black boys' and young men's experiences with court and custody as well as evidence on what works specifically in prison and probation settings (HMIP 2019). 


\section{Background and Context}

\subsection{Young Black Men in the Youth and Adult Criminal Justice Systems in England and Wales}

Black boys and young men are over-represented in the youth ${ }^{2}$ and adult criminal justice systems in England and Wales. Differences in outcomes between ethnic groups over time reveal that disparity between Black people and white people in the CJS is also widening (Ministry of Justice 2019). For example, in the last five years, whilst the proportion of stop and searches conducted on white suspects decreased (from $75 \%$ in $2014 / 15$ to $59 \%$ in $2018 / 19$ ), the numbers increased from $13 \%$ to $22 \%$ for Black suspects (Ministry of Justice 2019).

From the first point of contact in the youth justice system, there are a disproportionate number of Black children and young people entering the system as a result of discriminatory police stop and search practices. The most recent published statistics (for the year ending in March 2018) show that Black children (aged 10-17) were four times more likely than white children to be arrested. Second, the number of Black children and young people given a caution or sentence was also three times higher than that of the general 10-17-year-old population. Third, whilst there has been a reduction in the number of white children and young people sentenced for indictable offences between 2013 and 2018, the proportion of all occasions where Black children were sentenced for indictable offences increased from $13 \%$ to $21 \%$ over the same period. Analysis conducted by The Independent, which investigated how sentences given to Black children convicted of homicide compared with white children between 2009 and 2017, found that one in four Black teenage boys, found guilty of manslaughter, were given maximum jail terms, whilst white children were sentenced to no more than 10 years, with the majority getting less than four (Bulman 2018). Children from a Black minority ethnic background now make up one-third (33\%) of the custodial remand population. The proportion of children in youth custody from a Black background has been increasing and now accounts for a quarter of the youth custody population (Youth Justice Board and Ministry of Justice 2019).

This disproportionality continues into the adult CJS (Ministry of Justice 2019). For example, in the year ending in March 2019, those who identify as Black or Black British were 9.7 times as likely to be stopped than those who identify as white (Home Office 2019a). Analysis shows that stop and searches for drugs are more disproportionate than stop and searches for other offences: Black people were stopped and searched for drugs at almost nine times the rate of white people in 2016/17 (Shiner et al. 2018). In the same year, persons who identified as Black (or Black British) were over three times as likely to be arrested than those who identified themselves as white.

Research has shown that discrimination continues for BAME groups when they leave the CJS (Stacey 2019). A survey of 221 BAME individuals found that over three-quarters (78\%) felt that their minority ethnic background had made the problems they face as a result of their criminal record harder, with the vast majority (79\%) citing employment as one of the key difficulties they experienced as a result of their criminal record and exacerbated by their ethnicity (Stacey 2019). The survey found that African and Caribbean individuals were more effected. Black people are also simultaneously more likely to be victims of crime, with race as the most commonly recorded motivation for hate crimes in England and Wales. Race hate crimes accounted for around three-quarters of hate crime offences in 2018/19, increasing by 11\% from 2017/18 (Home Office 2019b).

\subsection{Experiences of Multiple Disadvantage}

Young Black men experience disadvantage across indicators of economic and social wellbeing, including education, employment, housing and living standards, and in health settings, in particular, mental health (The Bradley Commission 2013; Equality and Human Rights Commission 2016). Black Caribbean and dual Black Caribbean/white children have rates of permanent exclusion at about three

2 In England and Wales, the youth justice system deals with children and young people aged 10-17. 
times those for all pupils (Equality and Human Rights Commission 2016). Moreover, young Black people are over-represented in poor neighbourhoods where children are less well provided for and routes for advancement in education are constrained (Youth Justice Board 2010). Under-attainment of Black boys is a "major cause of entry into the criminal justice system" ((House of Commons Home Affairs Committee 2007), paragraph 113). Research evidence also suggests that children are still victims of bullying because of their ethnicity or religion (Ditch the Label 2015 cited in (Equality and Human Rights Commission 2016)). Research by the Equality and Human Rights Commission (2016) found that white people had a higher employment rate (at 74.7\%) than ethnic minorities (59.3\%) (cited in (Equality and Human Rights Commission 2016)). A study by the Trades Union Congress found that BAME workers are one-third more likely than white workers to be underemployed (Trades Union Congress 2016).

Further, Black young men are also over-represented in mental health care (The Bradley Commission 2013; Wainwright et al. 2019). Black men are two times more likely to be referred to mental health services through police or court services (Mullen et al. 2014). In research on the needs of young African and Caribbean men and mental health, findings indicate a wide range of causes of mental health problems, for example, abusive family upbringing, trauma, bullying, and stress. Barriers to accessing support were identified, including an inability to recognise the signs that more specialist support might be needed and concerns around reputation and stigma (Allen and Williams 2015).

\subsection{Political and Policy Context}

Concerns about the disproportionate numbers of young Black men in the youth and adult criminal justice systems in England and Wales have been raised in successive governments over several decades. In January 2016, David Cameron invited David Lammy MP to conduct a review of the treatment of and outcomes for BAME individuals in the CJS in England and Wales (Lammy 2017). The review covered the role of key criminal justice institutions in both the adult and youth justice systems, but Lammy stated that his "biggest concern" was with the youth justice system due to significant increases in disproportionality (Lammy 2017, p. 4).

The report highlighted the complex, multitude of factors that influence disproportionate representation of BAME people and made 35 recommendations at targeted various institutions in both the adult and youth justice systems. In 2018, the Ministry of Justice (MoJ) reported on progress made in relation to each recommendation of the Lammy Review (Ministry of Justice 2018). Examples highlighted by the MoJ focused on specific stages of the criminal justice system (prevention and charging decisions, courts, prisons and rehabilitation, and youth justice specifically). The progress identified was wide, ranging from funding for prevention programmes through the Early Intervention Youth Fund and the publication of guidance by the Crown Prosecution Service in relation to gangs (Ministry of Justice 2018). A number of bodies have also been set up to support recommendations made by the Lammy Review, for example, the Youth Justice Policy Unit in the MoJ and the External Advice and Scrutiny Panel established by Her Majesty's Prison and Probation Service (Mullen 2018). The response of the third sector has been somewhat critical of MoJ for not actively partnering with or specifically resourcing any organisations working directly with BAME groups as part of the implementation of the Lammy Review (Mullen 2018). In response to the Lammy Review, Clinks (2017) called for a clear strategy for the BAME population in the youth justice system focussed on testing interventions and staff training to support improved outcomes for BAME children. Rising disproportionality in the youth justice system since the Lammy Review was published has led to criticism that the government and justice agencies have not done enough (Parkes 2019).

The Lammy Review proceeded the Young Review, which set out to highlight the specific experiences and needs of Black and Muslim men aged 18-24 in the CJS (Mullen et al. 2014). The task group for the Young Review highlighted concerns regarding the disproportionate use of stop and search and the risk-driven nature of policing in the context of gang and anti-terrorism policies. A key aim of the Young Review was to consider how existing knowledge regarding the disproportionately negative 
outcomes experienced by Black and Muslim male offenders may be applied in the significantly changed environment of probation introduced under the Transforming Rehabilitation reforms (Mullen et al. 2014). The negative implications of the Transforming Rehabilitation agenda for minority groups and for voluntary sector organisations who work to deliver specific projects has been raised in the literature (see, for example, (Martin et al. 2016) and (Clinks 2018)). The Transforming Rehabilitation programme has been widely criticised for lacking attention to diversity with concerns raised from the beginning of a "one size fits all approach to offender supervision" (Frazer et al. 2014, p. 93). Research also suggests that specialist local services provided by third-sector organisations to BAME communities have suffered under the Transforming Rehabilitation agenda (Clinks 2018; National Audit Office 2019). Alongside this, the new Payment by Results system, a target-setting approach, particularly presents challenges for third-sector organisations. It means that community rehabilitation companies are dependent on meeting quantitative targets and outcomes. Hough (2016) pointed to the negative implications of Payment by Results on third-sector organisations in her research with a charity for BAME and Muslim Offenders, Arooj. Hough (2016, p. 76) stated that their programme "is likely to prove incompatible with the Payment by Results regime of cost-cutting, value-for-money and meeting targets within a specific time-frame". Additionally, Through the Gate resettlement services, introduced through the Transforming Rehabilitation reforms to support the transition from prison to the community, regarding accommodation, employment, finance, mental health, and substance misuse, have been failing to meet offenders' resettlement needs (National Audit Office 2019). A HM Inspectorate of Prisons (HMIP) inspection of Through the Gate services found that individual resettlement plans were process driven rather than focused on meeting individuals' needs; for example, many prisoners were released without accommodation, and none of the prisoners had been helped into employment (HMIP 2016).

\section{Intersectionality}

The literature in this field has emphasised the need to focus on the fluid, intersectional identities of Black and minority people living in Britain today (Apena 2007; Durrance et al. 2013; Glynn 2014, 2016; Wainwright and Larkins 2020). Both the Lammy and Young reviews were critical of a lack of recognition of the diversity of this group in the CJS in England and Wales and were critical of the lack of data on diversity (e.g., religious identity) gathered by criminal justice institutions. The Young Review describes the diversity among this group: "Young Black and/or Muslim men are far from a homogenous group and the intersection of ethnicity, faith, culture and age makes these social identities multi-faceted and shifting" (Mullen et al. 2014, p. 19). This idea of "shifting" or "fluid" identities emphasises that young people have multiple identifications and that an exclusive focus on ethnicity can ignore wider factors such as socio-economic status (White 2008; Webster 2012).

As Durrance et al. (2013, p. 138) suggest, articulating what it means to be from a Black and minority ethnic group in Britain today is a complex task demanding "recognition of various intersecting identities drawing on ethnic, religious, national and cultural reference points". Glynn (2016, p. 24) defines intersectionality as "an understanding of human beings as shaped by the interaction of different social locations". Central to this is an understanding that these interactions "occur within a context of connected systems and structures of power" (Glynn 2016, p. 24). Apena (2007) argues that racial identity is an important part of self-perception and that this needs to be taken into account when working with young Black people in the CJS.

\section{Experiences with the Youth and Adult Criminal Justice Systems in Wales}

Due to the lack of research specifically exploring boys' and young Black men's perceptions and experiences of the youth and adult criminal justice systems in England and Wales, this review also draws on research that has focused on the experience of other ethnic minorities (particularly young non-Black Muslim and Asian men). The literature is extremely limited in providing the voices of young Black men on their own experiences. Some of the available evidence is out of date and cannot account for changes in criminal justice systems/processes. 
Research evidence on BAME experiences highlights a lack of trust in the justice system in England and Wales. The Young Review, based on evidence gathered from a range of sources (e.g., previous research, discussion groups with service users in prison and community settings) found that experiences of discrimination and racism were common amongst those spoken to (Mullen et al. 2014). Drawing on a range of factors, Mullen et al. (2014, p. 32) state the following: "The evidence is clear that racism in custody can take different forms; directly from other inmates; directly from staff; and less overt discrimination in decision making". For example, BAME men spoken to in prison said that they were more likely to receive warnings and adjudications than their white counterparts, more likely to be found guilty than white prisoners even when they had been involved in the same incident, and that opportunities for purposeful activity that would allow them to work towards enhanced status were not equally distributed across prisoners of different ethnicities (Mullen et al. 2014). A lack of ethnic diversity of staff within criminal justice organisations was also raised. In Hunter's (2019, p. 119) research, youth justice professionals viewed discriminatory practices as both "widespread and important for understanding ethnic disproportionality" in the youth justice system. The majority of interviewees viewed stop and search as an intervention that has been used excessively on BME children and young people. In the Young Review, concerns were raised that policing and criminal justice is dominated by a risk-based operating model, which particularly impacts individuals whose behaviour is too often understood by society on the basis of stereotypical and prejudiced perceptions. As a result, Mullen et al. (2014) state that young BAME men are often assessed to be of a higher level of risk than their white counterparts.

Published in 2007, research on young Black men's and other minority ethnic groups' experience with policing in the West Midlands found a lack of trust and confidence in the police. Amongst the participants in the study, there was a belief that the police service has nothing to offer to them or to their communities (Sharp and Atherton 2007). In a mixed methods study examining stop and search and custody records in three police forces in England, May et al. (2010) found evidence that at some stages of the youth justice system, there may be discrimination against ethnic minorities. For example, dual ethnicity offenders and suspects were more likely than white people to be prosecuted than to be reprimanded or warned; Black and dual ethnicity defendants were more likely to be remanded in custody than white defendants; and, at the sentencing stage, dual ethnicity teenagers were more likely than others to be given a community sentence rather than a less serious first-tier penalty, such as referral orders and fines (May et al. 2010). Hopkins' (2015) research investigated whether defendants who were recorded by police officers as being from a $\mathrm{BAME}^{3}$ background were more likely to be sent to prison than those who were recorded as being from a white background in England and Wales. Logistic regression was employed to explore whether any independent associations were found between 12 broad offence groupings ${ }^{4}$, criminal history, gender, age, nationality, ethnicity, and being sentenced to prison compared with being sentenced to a community order or another type of disposal. A small but significant association was found between being from a BAME background (compared with being from a white background) and being sentenced to prison (compared with being sentenced to a community order or another type of punishment) (Hopkins 2015).

There are relatively few studies that focus on how ethnicity is experienced in prison, particularly by young Black men, and even fewer on young Black men's experience with the court system in England and Wales. Hunter's (2019) research, involving interviews with youth justice professionals, found evidence of harsher sentencing for BAME children in practice. A rapid evidence assessment of the effectiveness of correctional interventions in reducing reoffending or substance misuse among BAME people was conducted in 2018 (Shingler and Pope 2018). It included international literature

3 Hopkins (2015) notes that ethnicity was recorded using the five categories: White, Black, Asian, Other, and Unknown. Black, Asian, Other, and Unknown were combined to make the "BAME" category used here. Police officers also record nationality using over 300 categories.

4 These groups did not take into account degrees of offence seriousness. 
due to the lack of studies in England and Wales-only five studies included in the 11-study review were conducted in the UK. The review concluded that "there is still insufficient evidence relevant to understanding how to improve outcomes for individuals from a BAME background" (Shingler and Pope 2018, p. 2). A key finding of the review was that despite some evidence that the content of "standard correctional programmes" can be experienced as relevant to BAME participants, some studies suggest that programmes that are "culturally aware" and "sensitive and inclusive" and "delivered by culturally aware and sensitive staff" are likely to have better outcomes (Shingler and Pope 2018, p. 2). This review provides little insight into the specific experiences of young Black boys/men due to its focus on all BAME groups and males/females.

In the Young Review, most of the prisoners interviewed said that they experienced differential treatment as a result of race, ethnicity, or faith (Mullen et al. 2014). Barn et al.'s (2018) research explored Black and minority ethnic boys' perceptions of their experiences with custody using Inspectorate of Prisons' reports and associated surveys. Based on analysis of survey data $(\mathrm{N}=600)$, they found that BAME boys' experiences were consistently more negative at every stage of the custody process. Of several example of differential experiences, key examples included the following: BAME boys were significantly less likely than white boys to report being treated with respect when being searched upon entering a Youth Offender Institution or being offered help and support with smoking, loss of property, feeling scared, or feeling worried and upset/needing someone to talk to; in relation to physical restraint, just over half of BAME boys reported experiences of physical restraint (53\% BAME vs. $36 \%$ white) and relatively high levels of victimization by other young people because of ethnicity (7\% BAME vs. 2\% white), religion (5\% BAME vs. $1 \%$ white), or nationality (4\% BAME vs. $0 \%$ white) (Barn et al. 2018).

Research on media representations of young Black men has shown that young Black men are often associated with gang membership (Cushion et al. 2011). Research by Williams and Clarke (2016) found that that the gang label is disproportionately attributed to BAME people, when compared to both the size of BAME populations and the numbers of white British people flagged or registered as involved with gangs. Based on analysis of a range of official data sources (including police gang lists and comparative data on gangs and youth violence alongside a Joint Enterprise ${ }^{5}$ prisoners' survey), Williams and Clarke's (2016) examined the extent to which gang discourses influence the processes of criminalisation of young Black men and revealed that contemporary policing and prosecution strategies in relation to youth violence in England and Wales continue to be underpinned by racialised stereotypes.

In a comparative analysis of gangs and serious youth violence cohorts by ethnicity in Manchester and London, they found that BAME people are overwhelmingly identified and registered to "gang" lists, although they make up a much smaller proportion of those perpetuating youth violence. Williams and Clarke (2016) write that this means it cannot be assumed that the construction of police gang lists is an objective response to violence occurring within particular communities when the lists fail to map onto serious youth violence incidents. In their survey with Joint Enterprise prisoners, of which just over half (53.1\%) self-disclosed as belonging to a BAME group, Williams and Clarke (2016) found that the BAME group was serving longer sentences on average (22.3 years) when compared to the white group (19.6 years) and that BAME prisoners had on average 4.11 co-defendants compared to a figure of 3.19 for white British prisoners.

It has been argued that anti-gang intervention based upon a type of social profiling can lead to net-widening and can potentially compound the problem it is intended to address through social profiling, leading to "non-gang members" becoming part of the profile (White 2008). In discussions as part of the Young Review with community-based organisations, concerns about gang policy and the resulting police response, which identifies young BAME people as a risk rather than in need, were

5 Joint Enterprise is a doctrine of common law that has been developed by the courts in cases where more than one person is to be prosecuted for the same offence, and it has emerged as a prosecution tool for the collective punishment of groups where it can be proved that the suspects were "in it together" (Williams and Clarke 2016). 
raised (Mullen et al. 2014). There were indications that this focus on risk has led to younger BAME people entering the CJS, including those who are only on the periphery of gang activity.

\section{The Needs of Young BAME People Involved in Offending}

The Youth Justice Board aimed to explore whether there was a need for BME-specific interventions, specifically whether young offenders thought their needs would be better met through the provision of targeted interventions (Youth Justice Board 2010). In interviews with 93 young people largely from BAME backgrounds, $96 \%$ believed that the Youth Offending Team treated all young people fairly, regardless of their ethnicity (Youth Justice Board 2010).

The literature shows that the needs of BAME and/or Muslim young people in custody and leaving prisons are different from the general population (Youth Justice Board 2010). In a survey undertaken by Arooj, a charity that works with BAME and Muslim offenders, into the experiences of South Asian and Muslim ex-offenders in prison and resettlement, $36 \%$ of the 115 respondents stated that "specialist cultural and religious support would help them to stay out of trouble" (Mahmood and Hanif 2014).

A study of Youth Offending Team case files from 2006 specifically examined ASSET data to assess the difference in the needs of young males and females (Youth Justice Board 2010). Twelve factors relating to needs and risks were assessed in the ASSET tool, for example, living arrangements, family and personal relationships, education, training and employment, and emotional and mental health. The data suggested that dual ethnicity offenders had the greatest needs across the categories and displayed the greatest risk of reoffending.

\section{Desistance from Crime-Seeking to Understand the Experiences of Black Boys and Young Men}

Put simply, desistance literature has sought to understand the circumstances in which people stop offending. In 2007, in a paper exploring the impacts of desistance research for policy, McNeill and Weaver (2007) wrote that few studies have addressed the relationship between ethnicity, "race", and desistance. They stated that it is not an over-generalisation to suggest that almost nothing is known about the differences in desistance from crime between ethnic groups. More recently, academics in the field have argued that the possible role of "ethnic social structural differences" and their potential effect on desistance have been neglected (Calverley 2013, p. 7; Durrance et al. 2013). Wainwright and Larkins (2020) highlight that the words "race" and "racism" are not present in the HMIP (2016) review of UK desistance interventions and that the Youth Justice Board's library of effective practice contains only one resource that mentions how addressing the experience of racism can reduce offending. They called for guidance on how addressing race can enhance work with young people who have been involved in offending behaviour.

The work of Farrall and colleagues has demonstrated that the desistance process is likely to involve relapses and that one-size-fits-all interventions are unlikely to be effective and should instead be replaced by individual, holistic services (2002, 2006 cited in (Moffatt 2014)). Researchers in the UK have argued that cognitive behavioural programmes, used within the "What Works" initiative, inadequately take into consideration the specific problems face by Black and Asian offenders (Durrance and Williams 2006 cited in (Calverley 2013)). Wider use of culturally appropriate "empowerment" programmes, taught alongside promoting a positive view of ethnic identity, has been advocated. Calverley (2013) writes that such local programmes run by the probation service have often been small scale and short lived.

Over the last two decades, a body of work on desistance has evolved to focus on interpreting desistance research for practice (McNeill 2012). McNeill (2012) identifies six key emphases of this work: it must (1) consider issues of identity and diversity, (2) take into account the development of not only motivation but also hope, (3) be understood within the context of human relationships, (4) consider offenders' strengths and resources both personal and in their social networks, (5) involve interventions that work with offenders not on them, and (6) incorporate interventions that work on building human and social capital. McNeill and Maruna (2008) write that desistance is best understood within the context of 
human relationships-that social bonds can generate social capital, which leads to increased participation and inclusion in wider society (McNeill and Maruna 2008). More recently, McNeill (2018) has called for an understanding of rehabilitation focused on social relationships. He writes that "correctional agencies" must look beyond "personal rehabilitation" and consider the relational impacts of wider structural problems. The Young Review highlights the importance of social capital in creating resilient communities and the challenges of social deprivation (Mullen et al. 2014). As young BAME people often come from communities experiencing high levels of deprivation this is particularly pertinent. For example, employment has been found to be a key factor in the desistance process. Holding a criminal record has been shown to limit employment opportunities, which is particularly an issue for young BAME people.

Durrance et al. (2013, p. 146) argues that attention should be focused on the 'complex individual identities' of offenders from BAME backgrounds. Calverley (2013) states that consideration must also be given to differences in patterns of desistance between different ethnic groups. Durrance et al. (2013), citing Ward and Maruna (2007) and Maguire (2007), argue that alongside an assessment of risk, there is a need to explore offenders' values, goals, and strengths. An essential aspect of working towards these individual goals, Durrance writes, is through exploring the role of social networks of family and community as supports and dangers, which are not central to current assessment tools. Both Durrance and Calverley provide some examples in practice of a desistance-focused approach to working with minority ethnic offenders and argue that such an approach must be creative and focus on the multifaceted identities of minority ethnic offenders. Calverley (2013, p. 4) states: "Ethnicity must not be seen as an essential entity responsible in itself for producing differences. Instead, ethnicity is arguably best understood as an interactive factor with other determinants of desistance, as a significant co-variant".

The research of Glynn $(2014,2016)$ and Calverley (2013) has been critical to the development of knowledge regarding the desistance process for minority ethnic groups in the UK. Calverley's (2013) work has been central to theorising around desistance and race. His review of the literature on desistance and ethnicity found that most studies come from the U.S. Based on this review, he argued that there is a gap in knowledge regarding how identity change may operate as a mechanism in the desistance of UK-based minority ethnic groups (Calverley 2013).

Calverley's (2013) own research explored the factors and processes associated with desistance from crime amongst Black, Indian, and Bangladeshi offenders in the UK. The aim of his study was to first, gain deeper insight into the experiences of minority ethnic offenders as they try to desist from crime and, second, to examine the effect the community to which these offenders belong had on shaping their desires, actions, and efforts to stop offending. Based on 33 interviews with offenders (either residing in the community, sentenced to community sentence, or released from prison on licence), Calverley (2013) specifically explored the reasons why Black and dual heritage offenders do not desist as well as why they do desist. In contrast to the experiences of two South Asian groups in the sample, Calverley (2013) writes that the families of Black and dual heritage offenders provided fewer resources and lower levels of social capital. He outlines the major obstacles that Black and dual heritage members faced in their efforts to desist, for example, that resettlement was particularly difficult for this group, as they were often unable to return to the family home (Calverley 2013). Navigating the procedure of finding accommodation and employment impeded motivations to desist (Calverley 2013). The attempts of the 14 Black and dual ethnicity interviewees to secure employment were impeded by a lack of education qualifications and employment experience, as well as having little social or human capital with which to secure work. Calverley (2013) writes that there is certain evidence that the process of removing oneself from peers still involved in crime, a key process accompanying desistance, may be more problematic for Black and dual heritage offenders than other ethnic groups. A key conclusion made by Calverley (2013) was that the experiences of desistance amongst Black and dual heritage participants were individualistic as opposed to the more collective, collaborative experiences of the South Asian participants.

Glynn's $(2013,2014)$ research explored Black men's understandings and experiences of the racialisation of the crime/criminal justice systems and its impacts on the desistance process. His research 
found that many Black men re-entering the community from prison face obstacles to desisting from further offending based on "racialised barriers" encountered in the CJS and post-release (Glynn 2014). Glynn (2013) writes that the men he spoke to in his research faced a series of systemic, structural failures that restricted how they could actualise their desistance journey. For example, he highlights that whilst some of the former prisoners underwent skills training in preparation for work, they did not then get work on release. He also highlights that whilst training was given on social skills, relationships etc., there was no work alongside this to mitigate the stigma of having been in prison (Glynn 2013). As a consequence, Glynn (2013, p. 227) states that the "onus of desistance" is placed on Black men "without having any material means of re-incorporation". Issues of identity were also prevalent. Many of the Black men spoken to in the research believed that there was a lack of appreciation of what it means to be Black and British. He writes that many of the Black men spoken to felt "stripped of their identity" due to experiences of "invisibility" (Glynn 2013, p. 231).

A study exploring adult BAME offenders' experiences with resettlement on leaving prison, involving interviews with BAME prisoners and ex-prisoners and statutory and non-statutory providers of resettlement services, found that resettlement needs were generally spoken about as generic rather than "ethnically-specific" (Jacobson et al. 2010, p. 1). This led Jacobson et al. (2010) to argue that most resettlement needs of BAME offenders do not fundamentally differ from the needs of other offenders. However, whilst (ex-)prisoner respondents did not call for specialist resettlement provisions for BAME offenders, they felt that ethnic diversity and cultural sensitivity among resettlement staff was extremely important (Jacobson et al. 2010). Specialist provision of support for BAME offenders was also advocated for by most service providers in order to ensure that cultural differences in approaches to resettlement are sensitively dealt with.

Glynn (2016) has called for an intersectional model of desistance to be adopted to understand experiences of multiple oppression by offender groups. Glynn $(2014,2016)$ highlights that Black men's experiences in the CJS cannot be explained by race as a single category but, rather, by considering the interconnected issues associated with race, masculinity, poverty, and social disorganisation. He posits that the practical implications of taking such an approach to desistance for Black offenders would require "culturally competent rehabilitative processes" through networks and activities that support their desire to desist, which radically reframe interlocking oppressions of criminal justice processes that render them subordinate (Glynn 2016). Glynn (2016) posits that central to the intersectional model of desistance is a consideration of power and privilege in society in order for desistance research to move from a theoretical to a transformative paradigm rooted in the pursuit of social and racial justice. His intersectional model of desistance contains 11 elements that should be addressed in taking an intersectional approach to understanding Black men's desistance. These include a focus on the intersectional experiences of Black men in relation to their desistance from crime and a more multidimensional approach to understanding Black men's experiences with the CJS.

\section{Conclusions}

Race, racism, and ethnicity and the way the genealogy of these divisions is experienced within (in particular) the CJS is evidenced at each level of intervention. Despite continued awareness of discrimination and disproportionality in the English and Welsh youth and adult justice systems, there are significant gaps in knowledge, most notably on young Black men's experiences with court processes and in evidence of what works in prison and probation services. The voices of Black men have hardly been heard within discussions of desistance. A key limitation of this review was that many of the studies included here focused on BAME experiences more broadly rather than specifically on Black boys and young men. Whilst in the last decade the literature has begun to highlight the importance of considering intersectionality in order to understand the specific experiences of desistance amongst BAME men (Calverley 2013; Glynn 2014, 2016), youth and adult criminal justice responses in England/Wales arguably continue to be generic. The context of wider criminal justice reform, through Transforming Rehabilitation, has hindered the development of interventions/services that have a 
culturally focused approach. Whilst limited, the research evidence clearly shows a need for services that are culturally aware, sensitive, and inclusive to meet the needs of BAME groups (Shingler and Pope 2018). A recent summary of evidence stated: "overall there is insufficient robust evidence about 'what works' for BAME people in prison or on probation" (HMIP 2019). More research is needed to understand how Black and dual ethnicity boys and young men can be better supported by prison and probation services. With a focus on desistance, there is a clear need for greater investment in youth and adult justice rehabilitation services in England and Wales that are focussed not only on personal rehabilitation but also on the relational aspects of rehabilitation and the influence of social structures and cultural conditions (McNeill 2018). With the ending of community rehabilitation contracts brought forward to 2020 and the renationalisation of the probation system announced in 2019, there is an opportunity for change in the delivery of probation services in England and Wales. Alongside ensuring that the recommendations of the Lammy Review related to discrimination and fairness across the youth and criminal justice system are met, changes to the probation system must enable the provision of localised voluntary sector and smaller providers to provide "culturally competent rehabilitative processes", founded on an intersectional perspective of desistance (Glynn 2016). Finally, to enable these changes to the youth and criminal justice system to be meaningful for BAME children and young men, much more participatory co-produced research led by them needs to be undertaken to ensure that their voices and experiences are at the centre of these reforms.

Author Contributions: Conceptualization, L.R. and J.P.W.; methodology, L.R.; validation, L.R. and J.P.W.; formal analysis, L.R. and J.P.W.; writing-original draft preparation, L.R.; writing-review and editing, L.R. and J.P.W. All authors have read and agreed to the published version of the manuscript.

Funding: This article received no external funding.

Conflicts of Interest: The authors declare no conflict of interest.

\section{References}

Allen, Paul, and Patrick Williams. 2015. We Tell You Peer Based Community Research Interim Findings for Young Black Men's Perspectives on Mental Health. Available online: http://42ndstreet.org.uk/wordpress/ wp-content/uploads/2016/06/We-Tell-You-Interim-Report-November-2015-Final-Version.pdf (accessed on 9 December 2019).

Apena, Feyishola. 2007. Being Black and in Trouble: The Role of Self-perception in the Offending Behaviour of Black Youth. Youth Justice 7: 211-28. [CrossRef]

Barn, Ravinder, Martina Feilzer, and Nick Hardwick N. 2018. Black and Minority Ethnic Boys and Custody in England and Wales: Understanding subjective Experiences through an Analysis of Official Data. Social Sciences 7: 226. [CrossRef]

Bulman, May. 2018. Black teenage boys more likely to get maximum jail terms than white children. The Independent. July 29. Available online: https://www.independent.co.uk/news/uk/home-news/Black-boys-discriminationteenagers-children-white-racial-bias-prison-a8466606.html (accessed on 5 January 2020).

Calverley, Adam. 2013. Cultures of Desistance: Rehabiliation, Reintegration and Ethnic Minorities. Oxon: Routledge.

Clinks. 2017. Briefing on the Final Report of the Lammy Review. Available online: https://www.clinks.org/sites/ default/files/2018-09/lammy_review_briefing_final.pdf (accessed on 12 December 2019).

Clinks. 2018. Under Represented, Under Pressure, Under Resourced-The Voluntary Sector in Transforming Rehabilitation. Available online: https://www.clinks.org/sites/default/files/2018-10/clinks_track-tr_under_ final-web.pdf (accessed on 2 February 2020).

Cushion, Stephen, Kerry Moore, and John Jewell. 2011. Media Representations of Black Young Men and Boys. Available online: https://orca.cf.ac.uk/28559/1/2113275.pdf (accessed on 2 February 2020).

Durrance, Pauline, Liz Dixon, and Hindpal Singh Bhui. 2013. Creative working with Minority Ethnic Offenders. In What Else Works?: Creative Work with Offenders. Edited by Jo Brayford, Francis Cowe and John Deering. Devon: Willan, pp. 138-54.

Equality and Human Rights Commission. 2016. Healing a Divided Britain: The Need for a Comprehensive Race Equality Strategy Who Is It for? What Is Inside? Available 
online: https://www.equalityhumanrights.com/sites/default/files/healing_a_divided_britain_-_the_need_ for_a_comprehensive_race_equality_strategy.pdf (accessed on 4 February 2020).

Frazer, Lesley, Nicola Drinkwater, Jessica Mullen, Clare Hayes, Katie O’Donoghue, and Ellie Cumbo. 2014. Rehabilitation: What does good look like anyway? European Journal of Probation 6: 92-111. [CrossRef]

Glynn, Martin. 2013. Black Men's Desistance: The Radicalisation of Crime/Criminal Justice Systems and Its Impacts on the Desistance Process. Ph.D. thesis, Birmingham City University, Birmingham, UK.

Glynn, Martin. 2014. Black Men, Invisibility and Crime: Towards a Critical Race Theory of Desistance. Oxon: Routledge. Glynn, Martin. 2016. Towards an intersectional model of desistance for Black offenders. Safer Communities 15: 24-32. [CrossRef]

HMIP. 2016. An Inspection of Through the Gate Resettlement Services for Short-Term Prisoners. Available online: https://www.justiceinspectorates.gov.uk/cjji/wp-content/uploads/sites/2/2016/09/Through-the-Gate. pdf (accessed on 29 March 2020).

HMIP. 2019. Black and Minority Ethnic service Users-Effectiveness of Rehabilitative Services. Available online: https://www.gov.uk/guidance/Black-and-minority-ethnic-service-users-effectiveness-ofrehabilitative-services (accessed on 3 February 2020).

Home Office. 2019a. Police Powers and Procedures, England and Wales, Year Ending 31 March 2019. Available online: https://assets.publishing.service.gov.uk/government/uploads/system/uploads/attachment_data/file/ 841408/police-powers-procedures-mar19-hosb2519.pdf (accessed on 3 February 2020).

Home Office. 2019b. Hate Crime: England and Wales, 2018/19. Available online: https://assets.publishing.service. gov.uk/government/uploads/system/uploads/attachment_data/file/839172/hate-crime-1819-hosb2419.pdf (accessed on 3 February 2020).

Hopkins, Kathryn. 2015. Associations between Police-Recorded Ethnic Background and Being Sentenced to Prison in England and Wales. Available online: https://www.gov.uk/government/uploads/system/uploads/ attachment_data/file/479874/analysis-of-ethnicity-and-custodial-sentences.pdf (accessed on 4 December 2019).

Hough, Christine Victoria. 2016. Transforming Rehabilitation and its impact on a locally-based rehabilitation programme for Black and Minority Ethnic and Muslim offenders. European Journal of Probation 8: 68-81. [CrossRef]

House of Commons Home Affairs Committee. 2007. Young Black People and the Criminal Justice System: Second Report of the Session 2006-07 Volume 1. Available online: https://publications.parliament.uk/pa/cm200607/ cmselect/cmhaff/181/181i.pdf (accessed on 9 April 2020).

Hunter, Katie. 2019. Institutionalised Criminalisation: Black and Minority Ethnic Children and Looked After Children in the Youth Justice System in England and Wales. Ph.D. thesis, University of Liverpool, Liverpool, UK.

Jacobson, Jessica, Coretta Phillips, and Kimmett Edgar. 2010. 'Double Trouble'? Black, Asian and Minority Ethnic Offenders' Experiences of Resettlement. Available online: https://pdfs.semanticscholar.org/d006/ 07847ccb6722d2355b75fb1ae17da3c1b916.pdf (accessed on 3 February 2020).

Lammy, David. 2017. The Lammy Review: An Independent Review into the Treatment of, and Outcomes for, Black, Asian and Minority Ethnic Individuals in the Criminal Justice System. Available online: https://assets.publishing.service.gov.uk/government/uploads/system/uploads/attachment_data/file/ 643001/lammy-review-final-report.pdf (accessed on 3 February 2020).

Mahmood, Tariq, and Mohammad Hanif. 2014. Reducing Offending with BAME and Muslim Communities. Available online: http:/www.arooj.org.uk/wp-content/uploads/2019/02/AROOJ-RESEARCH-REVISEDNAPO-Version-OCT-2017.pdf (accessed on 4 December 2019).

Martin, Clive, Lesley Frazer, Ellie Cumbo, Clare Hayes, and Katie O’Donoghue. 2016. Paved with Good Intentions: The Way Ahead for Voluntary, Community and Social Enterprise Sector Organisations Background: The voluntary sector in criminal justice. In The Voluntary Sector and Criminal Justice. Edited by Anthea Hucklesby and Mary Corcoran. Basingstoke: Palgrave Macmillan, pp. 15-42.

May, Tiggey, Tracey Gyateng, and Mike Hough. 2010. Differential Treatment in the Youth Justice System. Available online: https://www.equalityhumanrights.com/sites/default/files/research_report_50_differential_treatment_ in_the_youth_justice_system.pdf (accessed on 4 December 2019).

McNeill, Fergus. 2012. Four forms of "offender" rehabilitation: Towards an interdisciplinary perspective. The British Psychological Society 17: 18-36. [CrossRef] 
McNeill, Fergus. 2018. Rehabilitation, corrections and society: The 2017 ICPA Distinguished Scholar Lecture. Advancing Corrections Journal 5: 10-20.

McNeill, Fergus, and Shadd Maruna. 2008. Giving up and giving back: Desistance, generativity and social work with offenders. In Developments in Social Work with Offenders. Edited by Gill McIvorand Peter Raynor. Series: Research Highlights in Social Work 48; London: Jessica Kingsley Publishers, pp. 224-339.

McNeill, Fergus, and Beth Weaver. 2007. Giving Up Crime: Directions for Policy. Available online: https: //www.sccjr.ac.uk/wp-content/uploads/2008/11/Giving_Up_Crime_tcm8-2569.pdf (accessed on 4 February 2020).

Ministry of Justice. 2018. Tackling Racial Disparity in the Criminal Justice System: 2018 Update. Available online: https://assets.publishing.service.gov.uk/government/uploads/system/uploads/attachment_data/file/ 747335/tackling-racial-disparity-criminal-justice-system-2018-update-web.pdf (accessed on 10 January 2020).

Ministry of Justice. 2019. Statistics on Race and the Criminal Justice System 2018. Available online: https://assets.publishing.service.gov.uk/government/uploads/system/uploads/attachment_data/file/ 849200/statistics-on-race-and-the-cjs-2018.pdf (accessed on 10 January 2020).

Moffatt, Stephen. 2014. Prospects for a Desistance Agenda. Available online: http://criminaljusticealliance.org/wpcontent/uploads/2015/03/Prospects-for-a-Desistance-Agenda-Full-report.pdf (accessed on 4 December 2019).

Mullen, Jessica. 2018. One Year on after Lammy, Where Is Race Equality in the CJS System now? Clinks. November 1. Available online: https://www.clinks.org/community/blog-posts/one-year-after-lammy-whererace-equality-cjs-now (accessed on 10 January 2020).

Mullen, Jessica, Mark Blake, Jeremy Crook, and Clive Marti. 2014. The Young Review: Improving Outcomes for Young Black and/or Muslim Men in the Criminal Justice System Final Report. Available online: http://www.youngreview.org.uk/sites/default/files/clinks_young-review_report_dec2014.pdf (accessed on 1 December 2019).

National Audit Office. 2019. Transforming Rehabilitation: Progress Review. Available online: https://www.nao.org. uk/wp-content/uploads/2019/02/Transforming-Rehabilitation-Progress-review.pdf (accessed on 2 February 2020).

Parkes, Joanne. 2019. Easing Disproportionately in Youth Custody. Children and Young People Now. July 29. Available online: https://www.cypnow.co.uk/other/article/easing-disproportionality-in-youth-custody (accessed on 1 February 2020).

Sharp, Douglas, and Susie Atherton. 2007. To Serve and Protect?: The Experiences of Policing in the Community of Young People from Black and Other Ethnic Minority Groups. British Journal of Criminology 47: 746-63. [CrossRef]

Shiner, Michael, Zoe Carre, Rebeka Delsol, and Niamh Eastwood. 2018. The Colour of Injustice: 'Race', Drugs and Law Enforcement in England and Wales. London: LSE.

Shingler, Jo, and Laura Pope. 2018. The Effectiveness of Rehabilitative Services for Black, Asian and Minority Ethnic People: A Rapid Evidence Assessment. Available online: https://assets.publishing.service.gov.uk/government/uploads/system/uploads/attachment_data/file/ 721977/_the-effectiveness-of-rehabilitative-services-for-BAME.pdf (accessed on 1 February 2020).

Stacey, Christopher. 2019. Double discrimination? The Impact of Criminal Records on People from Black, Asian and minority Ethnic Backgrounds. Available online: https:/www.unlock.org.uk/wp-content/uploads/ Double-discrimination-Full-report-July-2019.pdf (accessed on 4 February 2020).

The Bradley Commission. 2013. Black and Minority Ethnic Communities, Mental Health and Criminal Justice. Available online: https://www.centreformentalhealth.org.uk/sites/default/files/2018-09/Bradley_ Commission_briefing1_BME.pdf (accessed on 4 December 2019).

Trades Union Congress. 2016. BAME Workers a Third More Likely to Be Underemployed, Finds TUC Report. Trades Union Congress, August 22. Available online: https:/www.tuc.org.uk/equality-issues/Black-workers/ bame-workers-third-more-likely-be-underemployed-finds-tuc-report (accessed on 5 February 2020).

Wainwright, John P., and Cath Larkins. 2020. Race, ethnicity, young people and offending: The elephant in the room. Social Identities 26: 128-44. [CrossRef]

Wainwright, John P., Mike McKeown, and Malcolm Kinney. 2019. “In these streets": the saliency of place in an alternative Black mental health resource centre. International Journal of Human Rights in Healthcare 13: 31-44. [CrossRef]

Webster, Colin. 2012. Different forms of discrimination in the criminal justice system. Criminal Justice v. Racial Justice: Minority Ethnic Overrepresentation in the Criminal Justice System. Edited by Kjartan Pall Sveinsson. Available 
online: https://www.runnymedetrust.org/uploads/publications/pdfs/CriminalJusticeVRacialJustice-2012.pdf (accessed on 3 February 2020).

White, Rob. 2008. Disputed definitions and fluid identities: The limitations of social profiling in relation to ethnic youth gangs. Youth Justice 8: 149-61. [CrossRef]

Williams, Patrick, and Becky Clarke. 2016. Dangerous Associations: Joint Enterprise, Gangs and Racism-An Analysis of the Processes of Criminalisation. Available online: https: //www.crimeandjustice.org.uk/sites/crimeandjustice.org.uk/files/Dangerous\%20assocations\%20Joint\% 20Enterprise\%20gangs\%20and\%20racism.pdf (accessed on 1 December 2019).

Youth Justice Board. 2010. Exploring the Needs of Young Black and Minority Ethnic Offenders and the Provision of Targeted Interventions. Available online: https://assets.publishing.service.gov.uk/government/uploads/ system/uploads/attachment_data/file/354686/yjb-exploring-needs-young-Black-minority-ethnic-offenders. pdf (accessed on 1 February 2020).

Youth Justice Board and Ministry of Justice. 2019. Youth Justice Statistics 2017/18: England and Wales. Available online: https://assets.publishing.service.gov.uk/government/uploads/system/uploads/attachment_data/file/ 774866/youth_justice_statistics_bulletin_2017_2018.pdf (accessed on 2 February 2020).

(C) 2020 by the authors. Licensee MDPI, Basel, Switzerland. This article is an open access article distributed under the terms and conditions of the Creative Commons Attribution (CC BY) license (http://creativecommons.org/licenses/by/4.0/). 